\title{
The genetic association study between polymorphisms in uncoupling protein 2 and uncoupling protein 3 and metabolic data in dogs
}

\author{
Chihiro Udagawa' ${ }^{1}$, Naomi Tada', Junzo Asano ${ }^{1}$, Katsumi Ishioka², Kazuhiko Ochiai', Makoto Bonkobara ${ }^{3}$,
} Shuichi Tsuchida ${ }^{4}$ and Toshinori Omi ${ }^{1^{*}}$

\begin{abstract}
Background: The uncoupling proteins (UCPS) in the mitochondrial inner membrane are members of the mitochondrial anion carrier protein family that play an important role in energy homeostasis. Genetic association studies have shown that human UCP2 and UCP3 variants (SNPs and indels) are associated with obesity, insulin resistance, type 2 diabetes mellitus, and metabolic syndrome. The aim of this study was to examine the genetic association between polymorphisms in UCP2 and UCP3 and metabolic data in dogs.

Results: We identified 10 SNPs ( 9 intronic and 1 exonic) and 4 indels (intronic) in UCP2, and 13 SNPs (11 intronic and 2 exonic) and one indel (exonic) in UCP3, by DNA sequence analysis of 11 different dog breeds $(n=119)$. An association study between these UCP2 and UCP3 variants and the biochemical parameters of glucose, total cholesterol, lactate dehydrogenase and triglyceride in Labrador Retrievers $(n=50)$ showed that none of the UCP2 polymorphisms were significantly associated with the levels of these parameters. However, four UCP3 SNPs (intron 1) were significantly associated with total cholesterol levels. In addition, the allele frequencies of two of the four SNPs associated with higher total cholesterol levels in a breed that is susceptible to hypercholesterolemia (Shetland Sheepdogs, $n=30$ ), compared with the control breed (Shiba, $n=30$ ).

Conclusion: The results obtained from a limited number of individuals suggest that the UCP3 gene in dogs may be associated with total cholesterol levels. The examination of larger sample sizes and further analysis will lead to increased precision of these results.
\end{abstract}

Keywords: Dog, SNP, Indel polymorphism, UCP2, UCP3, Association study

\section{Background}

The uncoupling proteins (UCPs) in the mitochondrial inner membrane are members of the mitochondrial anion carrier protein family [1,2]. Mammals have five UCP homologs, of which UCP1, UCP2, and UCP3 are closely related, while UCP4 and UCP5 are more divergent from the other UCPs [3].

Based on genetic association studies, UCP2, UCP3, or both are reportedly associated with obesity, insulin resistance, type 2 diabetes mellitus, and metabolic syndrome in humans [4-11]. For example, a SNP in the 5'

\footnotetext{
* Correspondence: t.omi@nvlu.ac.jp

'Department of Basic Science, School of Veterinary Nursing and Technology, Faculty of Veterinary Science, Nippon Veterinary and Life Science University, 1-7-1 Kyonan-cho, Musashino, Tokyo 180-8602, Japan

Full list of author information is available at the end of the article
}

untranslated region in human $U C P 3$, the UCP3 -55CT SNP, is known to be a genetic marker associated with mRNA expression [12], elevated high density lipoprotein cholesterol levels, a reduced body mass index (BMI), weight, waist circumference, waist to hip ratio, fat mass, low density lipoprotein (LDL) cholesterol, and total cholesterol (T-Cho) [13-15].

The treatment and prevention of obesity and metabolicrelated diseases are also clinically important in dogs [16-25]. Our previous report showed that the nucleotide sequences, predicted amino acid sequences and the genomic structures of human $U C P 2$ and $U C P 3$ are highly homologous to the canine orthologs [26,27]. In this study, we investigate whether the $\operatorname{dog} U C P 2$ and $U C P 3$ genes are associated with alterations in metabolism. 


\section{Results and discussion}

Figure 1 shows a schematic representation of the canine $U C P 2$ and $U C P 3$ genes and the identified DNA polymorphisms from 119 animals from 11 breeds. For analysis of the dog $U C P 2$ gene, six regions were individually amplified from genomic DNA and sequenced. We then identified 10 SNPs (9 intronic and 1 exonic) and 4 indels (intronic) in $U C P 2$ (Figure 1, Additional file 1). In the dog UCP3 gene, 13 SNPs (11 intronic and 2 exonic) and 1 indel (exonic) were revealed by sequencing nine regions of this gene (Figure 1, Additional file 1).

To test the association between the $\operatorname{dog} U C P 2$ and $U C P 3$ genes and metabolic data, we determined the genotype of 50 Labrador Retrievers for each of 14 polymorphic sites (10 SNPs and 4 indels) in the UCP2 gene, and examined whether any of the genotypes were associated with biochemical measurements of glucose (GLU), total cholesterol (T-Cho), lactate dehydrogenase (LDH), or triglyceride (TG). To exclude any contamination by disease of the animals, we selected Labrador Retrievers that had undergone a health examination for breeding for guide dogs by the Kyushu Guide Dog Association.

The average of measurements was calculated with respect to the genotype group. Nine of the 14 loci in the UCP2 gene were polymorphic in this population of Labrador Retrievers. None of these DNA polymorphisms in the $U C P 2$ gene were significantly associated with any of the biochemical parameters in this study (Additional file 2). We also subjected the 14 polymorphic sites (13 SNPs and 1 indel) in the $U C P 3$ gene to this association analysis. Ten of the 14 sites were polymorphic in this population of Labrador Retrievers. There were no significant differences between genotype and GLU, LDH, or TG measurements for any polymorphic site. However, the T-Cho levels differed significantly among the genotype groups at four sites: $-4399 \mathrm{C} / \mathrm{T},-4339 \mathrm{~T} / \mathrm{C},-930 \mathrm{~T} /$ $\mathrm{C}$ and $-803 \mathrm{C} / \mathrm{T}$ in intron 1 of the $U C P 3$ gene $(U C P 3$ intron1). The average T-Cho levels in dogs carrying $\mathrm{CC}$ or $\mathrm{CT}$ at $-4399 \mathrm{C} / \mathrm{T}$ were $273.5 \pm 49.0$ and $237.2 \pm 53.3$, respectively. The average T-Cho levels for the TT, TC, or $\mathrm{CC}$ genotypes at $-4339 \mathrm{~T} / \mathrm{C}$ and $-930 \mathrm{~T} / \mathrm{C}$ were $264.3 \pm$ $49.6,276.9 \pm 49.5$, and $233.5 \pm 51.2$, respectively. Those for CC or CT at $-803 \mathrm{C} / \mathrm{T}$ were $271.6 \pm 49.5$ and $239.1 \pm$ 54.5 , respectively (Table 1 ). The genotype distributions were in a Hardy-Weinberg equilibrium.

Shetland Sheepdogs are considered to have a predisposition to primary hyperlipidemia as determined by the levels of cholesterol, triglycerides, and free fatty acids $[28,29]$. Therefore, we investigated the distribution of genotypes for SNPs and indels of the UCP2 and UCP3 genes in a population of Shetland Sheepdogs $(\mathrm{n}=30)$. Shiba $(\mathrm{n}=30)$ were also tested as a comparative contrast breed in this study. Statistically significant differences in allele frequency between the two breeds were found in five of the 14 polymorphic sites in UCP2 $(-3629 \mathrm{C} / \mathrm{G},-2931 \mathrm{~A} /$ $\mathrm{T},-748 \mathrm{G} / \mathrm{A},-636 \mathrm{~A} / \mathrm{G}$ and IVS6-133delTCTCCCC, Additional file 3). Four SNPs $(-4339 \mathrm{~T} / \mathrm{C},-930 \mathrm{~T} / \mathrm{C}$, $143 \mathrm{~A} / \mathrm{C}$ and IVS3+121T/C) of the $14 U C P 3$ polymorphic sites were significantly different in allele frequency between the two breeds (Table 2). Despite the

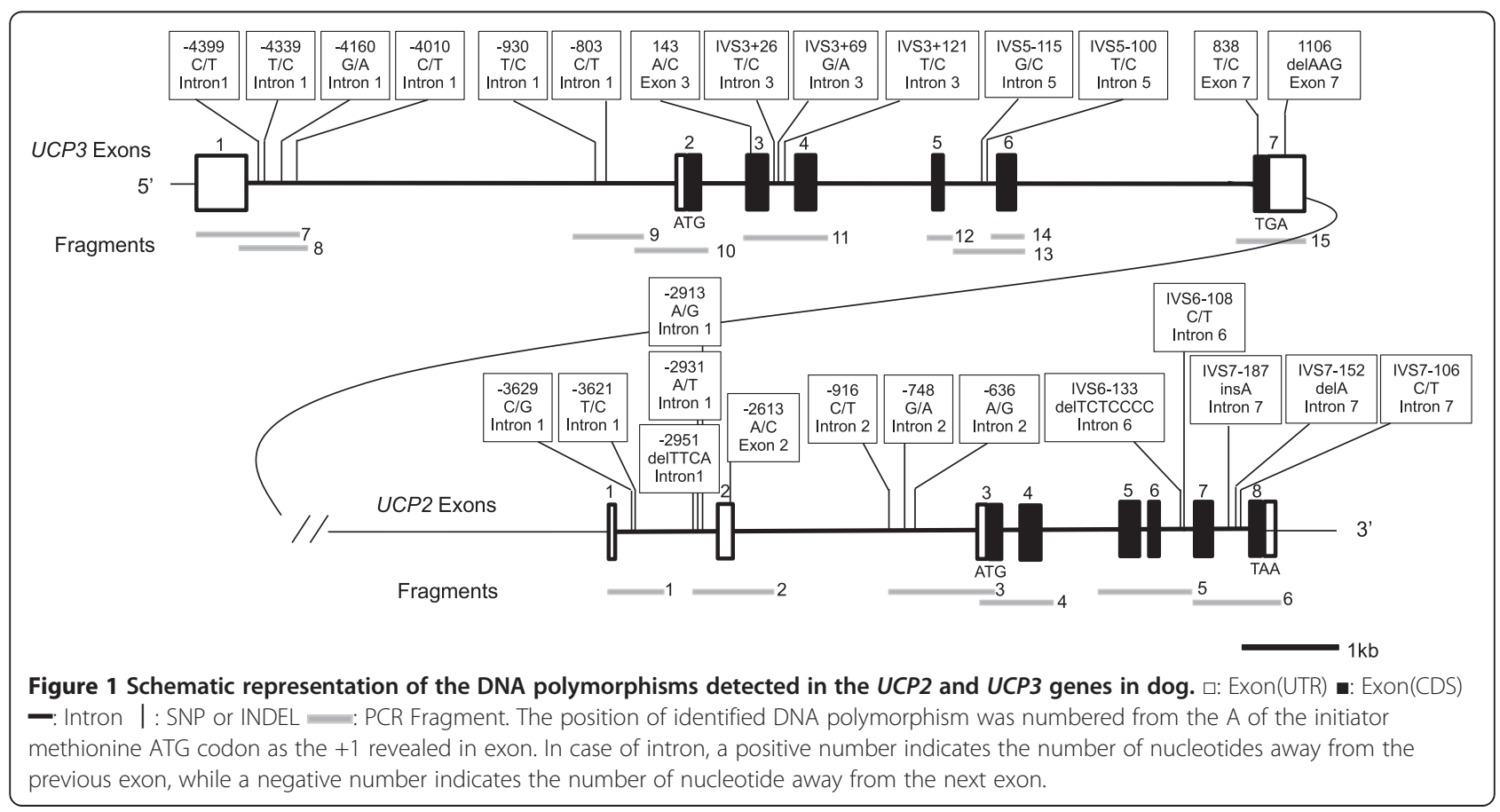


Table 1 Association analysis of UCP3 DNA polymorphisms with biochemical parameters among healthy Labrador Retrievers

\begin{tabular}{|c|c|c|c|c|c|}
\hline DNA polymorphism & Genotype & GLU & T-Cho & LDH & TG \\
\hline UCP3 & CC (34) & $97.1 \pm 8.4$ & $273.5 \pm 49.0$ & $55.9 \pm 18.0$ & $44.8 \pm 21.1$ \\
\hline \multirow[t]{3}{*}{$-4399 \mathrm{C} / \mathrm{T}$} & $\mathrm{CT}(16)$ & $98.8 \pm 14.5$ & $237.2 \pm 53.3$ & $55.7 \pm 13.5$ & $49.4 \pm 24.8$ \\
\hline & $\Pi \mathrm{T}(0)$ & - & - & - & - \\
\hline & $C C$ vs $C T+\pi$ & 0.597 & $0.021 *$ & 0.965 & 0.504 \\
\hline UCP3 & ТТ (8) & $94.5 \pm 5.4$ & $264.3 \pm 49.6$ & $55.3 \pm 13.7$ & $40.0 \pm 13.5$ \\
\hline \multirow[t]{4}{*}{$-4339 \mathrm{~T} / \mathrm{C}$} & $\mathrm{TC}(27)$ & $96.3 \pm 11.5$ & $276.9 \pm 49.5$ & $58.2 \pm 20.9$ & $50.4 \pm 24.8$ \\
\hline & CC (15) & $101.7 \pm 10.4$ & $233.5 \pm 51.2$ & $51.9 \pm 5.3$ & $42.3 \pm 20.5$ \\
\hline & TT vs TC + CC & 0.366 & 0.890 & 0.914 & 0.388 \\
\hline & $T+T C$ vs CC & 0.079 & $0.011^{*}$ & 0.279 & 0.408 \\
\hline UCP3 & CC (15) & $94.4 \pm 11.9$ & $255.5 \pm 52.6$ & $56.9 \pm 16.1$ & $51.2 \pm 23.2$ \\
\hline \multirow[t]{4}{*}{$-4010 C / T$} & CТ (29) & $98.7 \pm 10.2$ & $270.2 \pm 52.2$ & $56.5 \pm 18.5$ & $43.2 \pm 21.5$ \\
\hline & $\Pi(6)$ & $100.7 \pm 8.6$ & $237.7 \pm 54.7$ & $50.0 \pm 0.0$ & $48.7 \pm 24.6$ \\
\hline & $C C$ vs $C T+\pi$ & 0.159 & 0.580 & 0.763 & 0.310 \\
\hline & $\mathrm{CC}+\mathrm{CT}$ vs TT & 0.462 & 0.234 & 0.362 & 0.782 \\
\hline UCP3 & $\Pi(8)$ & $94.5 \pm 5.4$ & $264.3 \pm 49.6$ & $55.3 \pm 13.7$ & $40.0 \pm 13.5$ \\
\hline \multirow[t]{4}{*}{-930T/C } & TC (27) & $96.3 \pm 11.5$ & $276.9 \pm 49.5$ & $58.2 \pm 20.9$ & $50.4 \pm 24.8$ \\
\hline & CC (15) & $101.7 \pm 10.4$ & $233.5 \pm 51.2$ & $51.9 \pm 5.3$ & $42.3 \pm 20.5$ \\
\hline & $\Pi$ vs $T C+C C$ & 0.366 & 0.890 & 0.914 & 0.388 \\
\hline & $T T+T C$ vs CC & 0.079 & $0.011^{*}$ & 0.279 & 0.408 \\
\hline UCP3 & CC (35) & $96.9 \pm 8.4$ & $271.6 \pm 49.5$ & $55.7 \pm 17.7$ & $44.5 \pm 20.9$ \\
\hline \multirow[t]{3}{*}{$-803 C / T$} & $\mathrm{CT}(15)$ & $99.5 \pm 14.8$ & $239.1 \pm 54.5$ & $56.1 \pm 13.9$ & $50.5 \pm 25.2$ \\
\hline & $\Pi \mathrm{T}(0)$ & - & - & - & - \\
\hline & $C C$ vs $C T+\pi T$ & 0.431 & $0.045^{*}$ & 0.950 & 0.388 \\
\hline UCP3 & $\Pi \pi(15)$ & $94.4 \pm 11.9$ & $255.5 \pm 52.6$ & $56.9 \pm 16.1$ & $51.2 \pm 23.2$ \\
\hline \multirow[t]{4}{*}{ IVS3+26T/C } & TC (29) & $98.7 \pm 10.2$ & $270.2 \pm 52.2$ & $56.5 \pm 18.5$ & $43.2 \pm 21.5$ \\
\hline & CC (6) & $100.7 \pm 8.6$ & $237.7 \pm 54.7$ & $50.0 \pm 0.0$ & $48.7 \pm 24.6$ \\
\hline & TT vs TC + CC & 0.159 & 0.580 & 0.763 & 0.310 \\
\hline & $T T+T C$ vs CC & 0.462 & 0.234 & 0.362 & 0.782 \\
\hline UCP3 & GG (15) & $94.4 \pm 11.9$ & $255.5 \pm 52.6$ & $56.9 \pm 16.1$ & $51.2 \pm 23.2$ \\
\hline \multirow[t]{4}{*}{ IVS3+69G/A } & GA (29) & $98.7 \pm 10.2$ & $270.2 \pm 52.2$ & $56.5 \pm 18.5$ & $43.2 \pm 21.5$ \\
\hline & $\mathrm{AA}(6)$ & $100.7 \pm 8.6$ & $237.7 \pm 54.7$ & $50.0 \pm 0.0$ & $48.7 \pm 24.6$ \\
\hline & $G G$ vs $G A+A A$ & 0.159 & 0.580 & 0.763 & 0.310 \\
\hline & $G G+G A$ vs $A A$ & 0.462 & 0.234 & 0.362 & 0.782 \\
\hline UCP3 & GG (15) & $94.4 \pm 11.9$ & $255.5 \pm 52.6$ & $56.9 \pm 16.1$ & $51.2 \pm 23.2$ \\
\hline \multirow[t]{4}{*}{ IVS5-115G/C } & GC (29) & $98.7 \pm 10.2$ & $270.2 \pm 52.2$ & $56.5 \pm 18.5$ & $43.2 \pm 21.5$ \\
\hline & CC (6) & $100.7 \pm 8.6$ & $237.7 \pm 54.7$ & $50.0 \pm 0.0$ & $48.7 \pm 24.6$ \\
\hline & GG vs GC + CC & 0.159 & 0.580 & 0.763 & 0.310 \\
\hline & $\mathrm{GG}+\mathrm{GC}$ vs CC & 0.462 & 0.234 & 0.362 & 0.782 \\
\hline UCP3 & $\Pi(15)$ & $94.4 \pm 11.9$ & $255.5 \pm 52.6$ & $56.9 \pm 16.1$ & $51.2 \pm 23.2$ \\
\hline \multirow[t]{4}{*}{ IVS5-100T/C } & TC (29) & $98.7 \pm 10.2$ & $270.2 \pm 52.2$ & $56.5 \pm 18.5$ & $43.2 \pm 21.5$ \\
\hline & CC (6) & $100.7 \pm 8.6$ & $237.7 \pm 54.7$ & $50.0 \pm 0.0$ & $48.7 \pm 24.6$ \\
\hline & TT vs TC + CC & 0.159 & 0.580 & 0.763 & 0.310 \\
\hline & $\pi+T C$ vs CC & 0.462 & 0.234 & 0.362 & 0.782 \\
\hline
\end{tabular}


Table 1 Association analysis of UCP3 DNA polymorphisms with biochemical parameters among healthy Labrador Retrievers (Continued)

\begin{tabular}{cccccc}
\hline UCP3 & II (15) & $94.4 \pm 11.9$ & $255.5 \pm 52.6$ & $56.9 \pm 16.1$ & $51.2 \pm 23.2$ \\
1106delAAG & ID (29) & $98.7 \pm 10.2$ & $270.2 \pm 52.2$ & $56.5 \pm 18.5$ & $43.2 \pm 21.5$ \\
& DD (6) & $100.7 \pm 8.6$ & $237.7 \pm 54.7$ & $50.0 \pm 0.0$ & $48.7 \pm 24.6$ \\
& II vs ID + DD & 0.159 & 0.580 & 0.763 & 0.310 \\
& II + ID vs DD & 0.462 & 0.234 & 0.362 & 0.782 \\
\hline
\end{tabular}

Data are expressed as the mean \pm SD.

$p$-values were calculated by ANOVA. * and bold: $p<0.05$.

I: insertion, D: deletion, IVS: intervening sequence.

Loci which were not observed polymorphism in Labrador retriever, or were not detected $p$-value are not shown.

different genetic background in each of the dog breeds [30-32], the different allele frequencies in the UCP2 and $U C P 3$ polymorphic site between the two breeds may result from the susceptibility of Shetland Sheepdogs to hypercholesterolemia in a limited number of individuals.

The $\mathrm{T}$ allele at $-4339 \mathrm{~T} / \mathrm{C}$ and $-930 \mathrm{~T} / \mathrm{C}$ located in the UCP3 intron 1 is associated with higher T-Cho levels, as shown by two different experiments: the association between polymorphisms and metabolic data (Table 1), and the distribution of allele of genotype in the breed that is susceptible to hypercholesterolemia (Table 2). These results suggest that the dog $U C P 3$ gene might be associated with T-Cho levels in a limited number of individuals.

It is known that the peroxisome proliferator activated receptors (PPAR) ligands activate $U C P 3$ expression $[33,34]$. The $U C P 3$ intron 1 contains that the putative binding elements of MyoG/MyoD, PPAR $\gamma / R X R \alpha$ and SP1/SP3 that enhanced the UCP3 gene transcription mainly regulated by PPARs in hamster, rat, and mouse [33]. Recently, we find the similar nucleotide sequences of the PPAR $\gamma / \mathrm{RXR} \alpha$ element in the dog UCP3 intron 1 (Canine Genome Draft, NC_006603.3). These findings imply that the dog UCP3 intron 1 may be associated with regulation of $U C P 3$ gene expression. Further studies will be needed to demonstrate whether PPAR ligands bind or not this intronic region in dog.

With each genetic study, a different sample size is used to identify the candidate gene associating with genotypes and phenotypes in common diseases (multifactorial diseases) and/or single gene disorders. For instance, genomewide association studies (GWAS) have reported the candidate gene associated with a mild form of disproportionate dwarfism using 23 cases and 37 controls [35], atopic dermatitis using 91 cases and 88 controls [36], and the chromosomal region of Patellar Luxation using 45 cases and 40 controls [37]. Some of the candidate genes were also tested using more than a hundred samples. The examination of larger sample sizes and further analysis will lead to increased precision of our results. In addition, because the association analysis in this study was performed using only polymorphisms within the $U C P 2$ and $U C P 3$ genes, we cannot exclude the possibility that a gene that is closely linked to $U C P 3$ is causal.

\section{Conclusions}

A genetic association study between polymorphisms in the dog uncoupling protein 2 and 3 genes and metabolic data showed that the SNPs of the UCP3 intron 1 were associated with T-Cho levels in Labrador Retrievers. Alleles associated with high T-Cho levels of these polymorphisms were also present at higher frequencies in a breed that is susceptible to hypercholesterolemia (Shetland Sheepdogs), than in the control group (Shiba). The results obtained from a limited number of individuals suggest that the $U C P 3$ gene in dogs may be associated with total cholesterol levels. Therefore, the UCP3 gene could be an interesting target, not only for lipid metabolism, but also for the treatment and prevention of obesity and metabolic-related diseases in dogs.

\section{Methods}

\section{Animals and DNA}

All animal experiments were approved by The Experimental Animal Ethics Committee in Nippon Veterinary and Life Science University. The blood samples were originally collected at the Veterinary Medical Teaching Hospital at NVLU with the written consent of each owner or the Kyushu Guide Dog Association. The collection of samples was handled by licensed veterinarians only.

Panel 1, for the first SNP discovery, was collected from 11 dogs that represented 11 different breeds: Miniature Dachshund, Welsh Corgi, Labrador Retriever, Shetland Sheepdog, Beagle, Yorkshire Terrier, Dobermann, Whippet, Weimaraner, Papillon, and Shiba. Panel 2 was used for SNP discovery and a study of associations between SNP variants and biochemical parameters; these samples were collected from 50 Labrador Retrievers. Panel 3 was used for SNP discovery and an interbreed analysis was 
Table 2 Genotyping data and interbreed analysis of DNA polymorphisms in UCP3

\begin{tabular}{|c|c|c|c|c|c|c|c|}
\hline \multirow{2}{*}{$\begin{array}{c}\text { UCP3 DNA } \\
\text { polymorphism }\end{array}$} & \multirow[t]{2}{*}{ Genotype } & \multicolumn{2}{|c|}{ Number of samples } & \multirow[b]{2}{*}{$p$} & \multirow[b]{2}{*}{ Allele } & \multicolumn{2}{|c|}{ Allele frequency } \\
\hline & & Shiba & Shetland sheepdog & & & Shiba & Shetland sheepdog \\
\hline \multirow[t]{3}{*}{$-4399 \mathrm{C} / \mathrm{T}$} & CC & 29 & 30 & NS & $C$ & 0.98 & 1.00 \\
\hline & CT & 1 & 0 & $C C$ vs $C T+\pi$ & $\mathrm{T}$ & 0.02 & 0.00 \\
\hline & $\pi$ & 0 & 0 & & & & \\
\hline \multirow[t]{3}{*}{$-4339 \mathrm{~T} / \mathrm{C}$} & $\pi$ & 0 & 4 & $p<0.05$ & $\mathrm{~T}$ & 0.07 & 0.37 \\
\hline & $\mathrm{TC}$ & 4 & 14 & $\Pi+\mathrm{TC}$ vs CC & C & 0.93 & 0.63 \\
\hline & $C C$ & 26 & 12 & & & & \\
\hline \multirow[t]{3}{*}{$-4160 \mathrm{G} / \mathrm{A}$} & GG & 30 & 30 & & G & 1.00 & 1.00 \\
\hline & GA & 0 & 0 & ND & $A$ & 0.00 & 0.00 \\
\hline & $\mathrm{AA}$ & 0 & 0 & & & & \\
\hline \multirow[t]{3}{*}{$-4010 C / T$} & $\mathrm{CC}$ & 18 & 13 & NS & C & 0.75 & 0.70 \\
\hline & $C T$ & 9 & 16 & 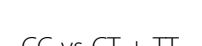 & $\mathrm{T}$ & 0.25 & 0.30 \\
\hline & $\Pi$ & 3 & 1 & Cevs & & & \\
\hline \multirow[t]{3}{*}{$-930 \mathrm{~T} / \mathrm{C}$} & $\pi$ & 0 & 4 & $p<0.05$ & $\mathrm{~T}$ & 0.07 & 0.37 \\
\hline & $\mathrm{TC}$ & 4 & 14 & $\pi+T C$ vs CC & C & 0.93 & 0.63 \\
\hline & CC & 26 & 12 & & & & \\
\hline \multirow[t]{3}{*}{$-803 C / T$} & CC & 30 & 30 & & C & 1.00 & 1.00 \\
\hline & CT & 0 & 0 & ND & $\mathrm{T}$ & 0.00 & 0.00 \\
\hline & $\Pi$ & 0 & 0 & & & & \\
\hline \multirow[t]{3}{*}{$143 \mathrm{~A} / \mathrm{C}$} & AA & 20 & 30 & $p<0.05$ & A & 0.82 & 1.00 \\
\hline & $A C$ & 9 & 0 & $A A$ vs $A C+C C$ & C & 0.18 & 0.00 \\
\hline & $\mathrm{CC}$ & 1 & 0 & & & & \\
\hline \multirow[t]{3}{*}{ IVS3+26T/C } & $\pi$ & 10 & 13 & NS & $\mathrm{T}$ & 0.57 & 0.70 \\
\hline & $\mathrm{TC}$ & 14 & 16 & $\Pi \mathrm{v} v \mathrm{TC}+\mathrm{CC}$ & C & 0.43 & 0.30 \\
\hline & $\mathrm{CC}$ & 6 & 1 & & & & \\
\hline \multirow[t]{3}{*}{ IVS3+69G/A } & GG & 18 & 13 & NS & G & 0.75 & 0.70 \\
\hline & GA & 9 & 16 & GG vs $G A+A A$ & A & 0.25 & 0.30 \\
\hline & AA & 3 & 1 & & & & \\
\hline \multirow[t]{3}{*}{ IVS3+121T/C } & $\pi$ & 29 & 14 & $p<0.05$ & $\mathrm{~T}$ & 0.98 & 0.67 \\
\hline & $\mathrm{TC}$ & 1 & 12 & $\Pi$ vs TC + CC & C & 0.02 & 0.33 \\
\hline & $\mathrm{CC}$ & 0 & 4 & & & & \\
\hline \multirow[t]{3}{*}{ IVS5-115G/C } & GG & 10 & 4 & NS & G & 0.55 & 0.37 \\
\hline & GC & 13 & 14 & $\mathrm{GG}+\mathrm{GC}$ vs CC & C & 0.45 & 0.63 \\
\hline & $\mathrm{CC}$ & 7 & 12 & & & & \\
\hline \multirow[t]{3}{*}{ IVS5-100T/C } & $\pi$ & 18 & 13 & NS & $\mathrm{T}$ & 0.75 & 0.70 \\
\hline & $\mathrm{TC}$ & 9 & 16 & $\Pi \mathrm{vs} T C+C C$ & C & 0.25 & 0.30 \\
\hline & $\mathrm{CC}$ & 3 & 1 & & & & \\
\hline \multirow[t]{3}{*}{$838 \mathrm{~T} / \mathrm{C}$} & $\pi$ & 28 & 30 & NS & $\mathrm{T}$ & 0.97 & 1.00 \\
\hline & $\mathrm{TC}$ & 2 & 0 & TT vs TC + CC & C & 0.03 & 0.00 \\
\hline & CC & 0 & 0 & & & & \\
\hline \multirow[t]{3}{*}{ 1106delAAG } & ins ins & 18 & 13 & NS & ins & 0.75 & 0.70 \\
\hline & ins del & 9 & 16 & $\|$ vs ID + DD & del & 0.25 & 0.30 \\
\hline & del del & 3 & 1 & & & & \\
\hline
\end{tabular}


collected from 30 Shetland Sheepdogs and 30 Shibas containing each one animals from Panel 1. A list of breeds and number of individuals are presented in Table 3. Genomic DNA was extracted from whole blood with the Puregene kit (Qiagen, Valencia CA, USA).

\section{PCR}

We used sequences of $U C P 2$ and UCP3 (Canine Genome Draft, NC_006603.3), to design 15 pairs of primers for amplification of each exon of the UCP2 and UCP3 genes (Table 4). Each PCR using TaKaRa Ex Taq was performed in a total volume of $25 \mu \mathrm{l}$ and contained 20 ng genomic DNA, $2.5 \mu \mathrm{l}$ 10× Ex Taq Buffer (including $20 \mathrm{mM}$ Tris- $\mathrm{HCl}, 100 \mathrm{mM} \mathrm{KCl}, 0.1 \mathrm{mM}$ EDTA, $1 \mathrm{mM}$ DTT, 0.5\% Tween 20, 0.5\% Nonidet P-40, 50\% Glycerol, $20 \mathrm{mM} \mathrm{Mg} 2^{+}$), $0.4 \mathrm{mM}$ of each primer, $200 \mu \mathrm{M}$ dNTP (dATP, dTTP, dCTP and dGTP), and $1 U$ TaKaRa Ex Taq (TaKaRa, Shiga, Japan). Each PCR using FastStart Taq DNA polymerase (Roche, Basel, Switzerland)) was performed in a total volume of $25 \mu \mathrm{l}$ and contained $20 \mathrm{ng}$ genomic DNA, $2.5 \mu \mathrm{l} 10 \times$ reaction Buffer (including $500 \mathrm{mM}$ Tris- $\mathrm{HCl}, 100 \mathrm{mM} \mathrm{KCl}, 50 \mathrm{mM}\left(\mathrm{NH}_{4}\right)_{2} \mathrm{SO}_{4}$, $20 \mathrm{mM} \mathrm{MgCl} 2$ ), $0.4 \mathrm{mM}$ of each primer (F12: $0.2 \mathrm{mM}$ of each primer), $200 \mu \mathrm{M}$ dNTP (dATP, dTTP, dCTP and dGTP), and $1 U$ FastStart Taq DNA polymerase. If

Table 3 List of 119 DNA samples from 11 breeds

\begin{tabular}{|c|c|c|c|c|}
\hline \multirow{2}{*}{$\begin{array}{l}\text { DNA } \\
\text { samples }\end{array}$} & \multirow[t]{2}{*}{ Breeds } & \multirow[t]{2}{*}{$\mathrm{N}$} & \multicolumn{2}{|c|}{ Sex } \\
\hline & & & Male & Female \\
\hline \multirow[t]{11}{*}{ Panel $1^{a}$} & Miniature Dachshund & 1 & & 1 \\
\hline & Welsh Corgi & 1 & 1 & \\
\hline & Labrador Retriever & 1 & 1 & \\
\hline & Shetland Sheepdog & 1 & 1 & \\
\hline & Beagle & 1 & & 1 \\
\hline & Yorkshire Terrier & 1 & 1 & \\
\hline & Dobermann & 1 & & 1 \\
\hline & Whippet & 1 & & 1 \\
\hline & Weimaraner & 1 & & 1 \\
\hline & Papillon & 1 & & 1 \\
\hline & Shiba & 1 & 1 & \\
\hline Panel $2^{a, b, d}$ & Labrador Retriever & 50 & 27 & 23 \\
\hline \multirow[t]{2}{*}{ Panel $3^{a, b, c}$} & Shetland Sheepdog & $30^{e}$ & 15 & 15 \\
\hline & Shiba & $30^{e}$ & 15 & 15 \\
\hline Total & & $119^{f}$ & 60 & 59 \\
\hline
\end{tabular}

N. Number of samples.

a. SNP discovery.

b.SNP genotyping.

c. Interbreed analysis.

d. Association analysis of DNA polymorphisms with biochemical parameters.

e. Include one individual of panel 1.

f. Total numbers of independent individuals. necessary, we used FastStart Taq for primer pairs that did not work with TaKaRa Ex Taq. The PCR reactions were performed on TaKaRa PCR Thermal Cycler Dice TP600 (TaKaRa). The conditions for PCR are shown in Table 5.

\section{Sequencing and SNP detection}

The PCR products were purified with High Pure PCR Product Purification Kit (Roche). Cycle sequencing was then performed with the Big Dye Terminator v3.1 kit (Applied Biosystems, Foster City CA, USA); each reaction was run in a $10 \mu \mathrm{l}$ reaction volume containing $1 \mu \mathrm{l}$ purified PCR amplification product, $1 \mu \mathrm{l}$ Ready Reaction Premix, $1.5 \mu \mathrm{l} 5 \times$ Big Dye Sequence Buffer, $1 \mu \mathrm{l}$ primer (1.6 $\mathrm{pmol} / \mu \mathrm{l})$, and $5.5 \mu \mathrm{l}$ sterile water. Cycle sequencing reactions were performed with the following conditions: $60 \mathrm{~s}$ at $96^{\circ} \mathrm{C}$ followed by 25 cycles of $10 \mathrm{~s}$ at $96^{\circ} \mathrm{C}, 5 \mathrm{~s}$ at $50^{\circ} \mathrm{C}$ and $4 \mathrm{~min}$ at $60^{\circ} \mathrm{C}$. BigDye Xterminator Purification kits were used according to the manufacturer's instructions (Applied Biosystems) to purify dye-labeled fragments. Samples were analyzed on an ABI PRISM 310 genetic analyzer (Applied Biosystems). We identified DNA polymorphisms by comparing each sequence with the reference sequence (Canine Genome Draft. NC_006603.3) by BLAST in NCBI (National Center for Biotechnology Information) and GENETYX program Ver. 11(GENETYX Corporation, Tokyo, Japan). The position of identified DNA polymorphism was numbered from the A of the initiator methionine ATG codon as the +1 revealed in exon. In case of intron, a positive number indicates the number of nucleotides away from the previous exon, while a negative number indicates the number of nucleotide away from the next exon.

\section{Measurement of biochemical parameters}

Blood samples were collected into heparinized plastic tubes at least $12 \mathrm{~h}$ postprandial. Plasma was separated by centrifugation at $1500 \times \mathrm{g}$ for $10 \mathrm{~min}$. Glucose (GLU), triglyceride (TG), total cholesterol (T-Cho), and lactate dehydrogenase (LDH) were measured using a Spotchem EM SP-4430 (Arkray, Kyoto, Japan) with the manufacturer's reagents.

\section{Statistical analysis}

Deviation from the Hardy-Weinberg equilibrium was assessed by the Chi-squared test. SNPAlyze (Dynacom, Chiba, Japan) was used to estimate haplotype frequencies. Genotype frequencies were compared using the Fisher's exact test. Differences of $p<0.05$ were considered statistically significant. Associations between genotype frequencies and metabolic data were analyzed by one-way analysis of variance (ANOVA). 
Table 4 Sequences of primers for PCR

\begin{tabular}{|c|c|c|c|c|c|c|}
\hline Gene & Fragment & Primer & $\begin{array}{l}\text { Primer sequences } \\
\qquad\left(5^{\prime}-3^{\prime}\right)\end{array}$ & $\begin{array}{l}\text { Range of PCR } \\
\text { amplification }^{\mathrm{a}}\end{array}$ & $\begin{array}{l}\text { size } \\
\text { (bp) }\end{array}$ & Region $^{b}$ \\
\hline \multirow[t]{12}{*}{ UCP2 } & \multirow{2}{*}{ F1 } & UCP2F1-F & CAGCTCTCGGCTTGTGAGC & \multirow{2}{*}{$24304468-24305048$} & \multirow{2}{*}{581} & \multirow[t]{2}{*}{ Exon 1 , Intron 1} \\
\hline & & UCP2F1-R & CACAACAGTCAGCAGACTGG & & & \\
\hline & \multirow{2}{*}{$F 2$} & UCP2F2-F & CCTTGCTGGAGTGTAATCTG & \multirow{2}{*}{$24305288-24306125$} & \multirow{2}{*}{838} & \multirow[t]{2}{*}{ Intron 1, Exon 2, Intron 2} \\
\hline & & UCP2F2-R & TGGGTTTGCCCAGGTCTTTC & & & \\
\hline & \multirow{2}{*}{ F3 } & UCP2F3-F & TACCAACTCTTCCATACCTC & \multirow{2}{*}{$24307315-24308410$} & \multirow{2}{*}{1096} & \multirow[t]{2}{*}{ Intron 2, Exon 3} \\
\hline & & UCP2F3-R & ATGCAGGCAGCTGTGCCAG & & & \\
\hline & \multirow{2}{*}{ F4 } & UCP2F4-F & TGAGCAGGACAGGACTGTT & \multirow{2}{*}{ 24308186-24308944 } & \multirow{2}{*}{759} & \multirow[t]{2}{*}{ Exon 3, Intron 3, Exon 4, Intron 4} \\
\hline & & UCP2F4-R & AAAGGAGCTATACAGCAAATCA & & & \\
\hline & \multirow{2}{*}{ F5 } & UCP2F5-F & TCTCAGAGCATTTACTCTGCT & \multirow{2}{*}{$24309392-24310367$} & \multirow{2}{*}{976} & \multirow[t]{2}{*}{ Intron 4, Exon 5, Intron 5, Exon 6, Intron 6} \\
\hline & & UCP2F5-R & AGAAAAGGCAGTCAGGACTC & & & \\
\hline & \multirow{2}{*}{ F6 } & UCP2F6-F & TCСТСССССТCAAACCATCA & \multirow{2}{*}{$24310274-24311183$} & \multirow{2}{*}{910} & \multirow[t]{2}{*}{ Intron 6, Exon 7, Intron 7, Exon 8} \\
\hline & & UCP2F6-R & GAAAGGGAGGTGGTGGGAA & & & \\
\hline \multirow[t]{18}{*}{ UCP3 } & \multirow{2}{*}{ F7 } & UCP3F7-F & ATAGTACTTACCTCATAGGGT & \multirow{2}{*}{$24277647-24278722$} & \multirow{2}{*}{1076} & \multirow[t]{2}{*}{$5^{\prime} \mathrm{Fl}$, Exon 1, Intron 1} \\
\hline & & UCP3F7-R & TATCTGTTCTCCATGGCAGC & & & \\
\hline & $\mathrm{F} 8$ & UCP3F8-F & CTAAGGAGCCTTAAGGGAAC & $24278114-24278825$ & 712 & Exon 1, Intron 1 \\
\hline & 10 & UCP3F8-R & TTCAGGGAGAGCTCAGGATC & 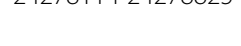 & Tाz & \\
\hline & FO & UCP3F9-F & ACGCTACAGGTATGTGTGAG & 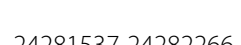 & 730 & Intron 1 \\
\hline & 等 & UCP3F9-R & CCTGAAGTGTACAGAGAGCC & $24 \angle 01351=24 \angle 0 \angle 200$ & (150 & \\
\hline & F10 & UCP3F10-F & TAACTAACAGTTTAGGTGAGTC & $4282174-24382933$ & 760 & Intron 1, Exon 2, Intron 2 \\
\hline & 10 & UCP3F10-R & TGCTCAGAGTTCTGTGTGAAG & 2420217424202930 & 100 & \\
\hline & F11 & UCP3F11-F & CAGGTCCTTCTGCACCCAG & $24283244-24284111$ & 868 & Intron 2, Exon 3, Intron 3, Exon 4, Intron 4 \\
\hline & ז & UCP3F11-R & TCATTCTGGGAGTTCCCTCC & & & \\
\hline & $\mathrm{F} 12$ & UCP3F12-F & CCTGTGGCCTTGCAACCAGA & $24285138-24285396$ & 250 & Intron 4, Exon 5, Intron 5 \\
\hline & Tr & UCP3F12-R & TGTTACCTCTGAGTGGTGCC & 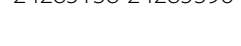 & 200 & \\
\hline & $\mathrm{F} 13$ & UCP3F13-F & GGCACCACTCAGAGGTAACA & $24285377-24286088$ & 712 & Intron 5, Exon 6, Intron 6 \\
\hline & 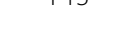 & UCP3F13-R & TGGGAAGGGATGTTGGATGC & 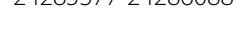 & 1012 & \\
\hline & F14 & UCP3F14-F & GCACTATCGTTACACTCAAGG & $24285748-24286088$ & 341 & Intron 5, Exon 6, Intron 6 \\
\hline & 1174 & UCP3F14-R & TGGGAAGGGATGTTGGATGC & $24 \angle 007,40=24 \angle 00000$ & 341 & \\
\hline & F15 & UCP3F15-F & TAACTGCCTAACACAGAACC & $24288288-24289004$ & 717 & Intron 6, Exon 7 \\
\hline & (1) & UCP3F15-R & TTCAGCCTTTCCTGTACACA & & & \\
\hline
\end{tabular}

a. Number of nucleotide position is from canine genome draft (CGD) NC_006603.3.

b. Fl: Flanking region Start codon is located in Exon 3 in UCP2 and Exon 2 in UCP3. Stop codon is located in Exon 8 in UCP2 and Exon 7 in UCP3.

\section{Additional files}

Additional file 1: Description and localization of identified DNA polymorphisms in dog UCP2 and UCP3 genes.

Additional file 2: Association analysis of UCP2 DNA polymorphisms with biochemical parameters among healthy Labrador Retrievers.

Additional file 3: Genotyping data and interbreed analysis of DNA polymorphisms in UCP2.

\section{Competing interests}

The authors declare that they have no competing interests.
Authors' contributions

CU contributed to designing the study, genotypes, performing the statistical analysis, and drafting the manuscript. NT and JA participated in collection of data and clinical test. $\mathrm{KI}, \mathrm{KO}, \mathrm{MB}$, and ST participated in study design and the manuscript editing. TO participated in experimental design, data collection, data analysis, and drafting of the manuscript. All authors read and approved the final manuscript.

\section{Acknowledgement}

We are thankful to the Department of Veterinary Clinical Pathology and the medical staff at Nippon Veterinary and Life Science University (NVLU) in Musashino Tokyo, and to the Kyushu Guide Dog Association in Itoshima, Fukuoka for biological samples. 
Table 5 Conditions for PCR

\begin{tabular}{|c|c|c|c|c|c|c|c|}
\hline Fragment & $\mathrm{Taq}^{\mathrm{a}}$ & Initial denature $\left({ }^{\circ} \mathrm{C} / \mathrm{m}\right)^{b}$ & Denature $\left({ }^{\circ} \mathrm{C} / \mathrm{m}\right)^{b}$ & Annealing $\left({ }^{\circ} \mathrm{C} / \mathrm{s}\right)^{\mathrm{b}}$ & Extention $\left({ }^{\circ} \mathrm{C} / \mathrm{m}\right)^{\mathrm{b}}$ & Cycle & Final extention $\left({ }^{\circ} \mathrm{C} / \mathrm{m}\right)^{\mathrm{b}}$ \\
\hline $\mathrm{F} 1$ & $\mathrm{~F}$ & $95 / 4$ & $95 / 1$ & $57 / 30$ & $72 / 1$ & 35 & $72 / 7$ \\
\hline F2 & E & $95 / 1$ & $95 / 1$ & $60 / 30$ & $72 / 1$ & 35 & $72 / 7$ \\
\hline F3 & $\mathrm{F}$ & $95 / 4$ & $95 / 1$ & $60 / 10$ & $72 / 1$ & 30 & $72 / 7$ \\
\hline F4 & $\mathrm{E}$ & $95 / 1$ & $95 / 1$ & $60 / 30$ & $72 / 1$ & 35 & $72 / 7$ \\
\hline F5 & $\mathrm{F}$ & $95 / 4$ & $95 / 1$ & $60 / 30$ & $72 / 1$ & 35 & $72 / 7$ \\
\hline F6 & $\mathrm{E}$ & $95 / 1$ & $95 / 1$ & $62 / 30$ & $72 / 1$ & 35 & $72 / 7$ \\
\hline F7 & $E$ & $95 / 1$ & $95 / 1$ & $60 / 15$ & $72 / 1$ & 34 & $72 / 7$ \\
\hline F8 & $\mathrm{F}$ & $95 / 4$ & $95 / 1$ & $62 / 30$ & $72 / 1$ & 35 & $72 / 7$ \\
\hline F9 & $\mathrm{F}$ & $95 / 4$ & $95 / 1$ & $62 / 30$ & $72 / 1$ & 35 & $72 / 7$ \\
\hline F10 & $E$ & $95 / 1$ & $95 / 1$ & $60 / 30$ & $72 / 1$ & 35 & $72 / 7$ \\
\hline F11 & $\mathrm{F}$ & $95 / 4$ & $95 / 1$ & $62 / 15$ & $72 / 1$ & 32 & $72 / 7$ \\
\hline F12 & E & $95 / 1$ & $95 / 1$ & $60 / 30$ & $72 / 1$ & 35 & $72 / 7$ \\
\hline F13 & $E$ & $95 / 1$ & $95 / 1$ & $60 / 30$ & $72 / 1$ & 35 & $72 / 7$ \\
\hline F14 & $E$ & $95 / 1$ & $95 / 1$ & $60 / 30$ & $72 / 1$ & 35 & $72 / 7$ \\
\hline F15 & E & $95 / 1$ & $95 / 1$ & $60 / 30$ & $72 / 1$ & 35 & $72 / 7$ \\
\hline
\end{tabular}

a. Taq polymerase: $\mathrm{E}=$ ExTaq (TaKaRa), $\mathrm{F}=$ Fast start Taq (Roche).

b. m: minutes s: seconds.

\section{Author details}

'Department of Basic Science, School of Veterinary Nursing and Technology, Faculty of Veterinary Science, Nippon Veterinary and Life Science University, 1-7-1 Kyonan-cho, Musashino, Tokyo 180-8602, Japan. ²Department of Veterinary Nursing, School of Veterinary Nursing and Technology, Faculty of Veterinary Science, Nippon Veterinary and Life Science University, 1-7-1 Kyonan-cho, Musashino, Tokyo 180-8602, Japan. ${ }^{3}$ Department of Veterinary Clinical Pathology, Nippon Veterinary and Life Science University, 1-7-1 Kyonan-cho, Musashino, Tokyo 180-8602, Japan. ${ }^{4}$ Laboratory of Comparative Cellular Biology, Nippon Veterinary and Life Science University, 1-7-1 Kyonan-cho, Musashino, Tokyo 180-8602, Japan.

Received: 26 September 2014 Accepted: 25 November 2014 Published: 11 December 2014

\section{References}

1. Nicholls DG, Locke RM: Thermogenic mechanisms in brown fat. Physiol Rev 1984, 64:1-64.

2. Boss O, Muzzin P, Giacobino JP: The uncoupling proteins, a review. Eur J Endocrinol 1998, 139:1-9.

3. Ricquier D, Bouillaud F: The uncoupling protein homologues: UCP1, UCP2, UCP3, StUCP and AtUCP. Biochem J 2000, 345:161-179.

4. Schrauwen P, Walder K, Ravussin E: Human uncoupling proteins and obesity. Obes Res 1999, 7:97-105.

5. Kagawa Y, Yanagisawa Y, Hasegawa K, Suzuki H, Yasuda K, Kudo H, Abe M, Matsuda S, Ishikawa Y, Tsuchiya N, Sato A, Umetsu K, Kagawa Y: Single nucleotide polymorphisms of thrifty genes for energy metabolism: evolutionary origins and prospects for intervention to prevent obesityrelated diseases. Biochem Biophys Res Commun 2002, 295:207-222.

6. Reis AF, Dubois-Laforgue D, Bellanné-Chantelot C, Timsit J, Velho G: A polymorphism in the promoter of UCP2 gene modulates lipid levels in patients with type 2 diabetes. Mol Genet Metab 2004, 82:339-344.

7. Yoon Y, Park BL, Cha MH, Kim KS, Cheong HS, Choi YH, Shin HD: Effects of genetic polymorphisms of UCP2 and UCP3 on very low calorie dietinduced body fat reduction in Korean female subjects. Biochem Biophys Res Commun 2007, 359:451-456.

8. Chan $C B$, Harper ME: Uncoupling proteins: role in insulin resistance and insulin insufficiency. Curr Diabetes Rev 2006, 2:271-283.
9. Lee HJ, Ryu HJ, Shin HD, Park BL, Kim JY, Cho YM, Park KS, Song J, Oh B: Associations between polymorphisms in the mitochondrial uncoupling proteins (UCPs) with T2DM. Clin Chim Acta 2008, 398:27-33.

10. Oktavianthi S, Trimarsanto H, Febinia CA, Suastika K, Saraswati MR, Dwipayana P, Arindrarto W, Sudoyo H, Malik SG: Uncoupling protein 2 gene polymorphisms are associated with obesity. Cardiovasc Diabetol 2012, 11:41.

11. De Souza BM, Brondani LA, Bouças AP, Sortica DA, Kramer CK, Canani LH, Leitão CB, Crispim D: Associations between UCP1-3826A/G, UCP2-866G/ A, Ala55Val and Ins/Del, and UCP3-55C/T polymorphisms and susceptibility to type 2 diabetes mellitus: case-control study and metaanalysis. PLoS One 2013, 8:e54259.

12. Schrauwen P, Xia J, Walder K, Snitker S, Ravussin E: A novel polymorphism in the proximal UCP3 promoter region: effect on skeletal muscle UCP3 mRNA expression and obesity in male non-diabetic Pima Indians. Int J Obes Relat Metab Disord 1999, 23:1242-1245.

13. Hamada T, Kotani K, Fujiwara S, Sano Y, Domichi M, Tsuzaki K, Sakane N: The common $-55 \mathrm{C} / \mathrm{T}$ polymorphism in the promoter region of the uncoupling protein 3 gene reduces prevalence of obesity and elevates serum high-density lipoprotein cholesterol levels in the general Japanese population. Metabolism 2008, 57:410-415.

14. De Luis DA, Aller R, Izaola O, De La Fuente B, Conde R, Eiros Bouza JM: Relation of $-55 C T$ polymorphism of UCP3 gene with weight loss and metabolic changes after a high monounsaturated fat diet in obese non diabetic patients. Eur Rev Med Pharmacol Sci 2013, 17:2810-2815.

15. Salopuro T, Pulkkinen L, Lindström J, Kolehmainen M, Tolppanen AM, Eriksson JG, Valle TT, Aunola S, llanne-Parikka P, Keinänen-Kiukaanniemi S, Tuomilehto J, Laakso M, Uusitupa M: Variation in the UCP2 and UCP3 genes associates with abdominal obesity and serum lipids: the Finnish Diabetes Prevention Study. BMC Med Genet 2009, 10:94.

16. Edney AT, Smith PM: Study of obesity in dogs visiting veterinary practices in the United Kingdom. Vet Rec 1986, 118:391-396.

17. Jeusette IC, Lhoest ET, Istasse LP, Diez MO: Influence of obesity on plasma lipid and lipoprotein concentrations in dogs. Am J Vet Res 2005, 66:81-86.

18. Laflamme DP: Understanding and managing obesity in dogs and cats. Vet Clin North Am Small Anim Pract 2006, 36:1283-1295.

19. Ishioka K, Omachi A, Sagawa M, Shibata H, Honjoh T, Kimura K, Saito M: Canine adiponectin: CDNA structure, mRNA expression in adipose tissues and reduced plasma levels in obesity. Res Vet Sci 2006, 80:127-132. 
20. German AJ, Hervera M, Hunter L, Holden SL, Morris PJ, Biourge V, Trayhurn $P$ : Improvement in insulin resistance and reduction in plasma inflammatory adipokines after weight loss in obese dogs. Domest Anim Endocrinol 2009, 37:214-226.

21. Zoran DL: Obesity in dogs and cats: a metabolic and endocrine disorder. Vet Clin North Am Small Anim Pract 2010, 40:221-239.

22. Tvarijonaviciute A, Ceron JJ, Holden SL, Cuthbertson DJ, Biourge V, Morris PJ, German AJ: Obesity-related metabolic dysfunction in dogs: a comparison with human metabolic syndrome. BMC Vet Res 2012, 8:147.

23. Axelsson E, Ratnakumar A, Arendt ML, Maqbool K, Webster MT, Perloski M, Liberg O, Arnemo JM, Hedhammar A, Lindblad-Toh K: The genomic signature of dog domestication reveals adaptation to a starch-rich diet. Nature 2013, 495:360-364.

24. Park HJ, Lee SE, Oh JH, Seo KW, Song KH: Leptin, adiponectin and serotonin levels in lean and obese dogs. BMC Vet Res 2014, 10:113

25. Kawasumi K, Kashiwado N, Okada Y, Sawamura M, Sasaki Y, Iwazaki E, Mori $\mathrm{N}$, Yamamoto I, Arai T: Age effects on plasma cholesterol and triglyceride profiles and metabolite concentrations in dogs. BMC Vet Res 2014, 10:57.

26. Ishioka K, Kanehira K, Sasaki N, Kitamura H, Kimura K, Saito M: Canine mitochondrial uncoupling proteins: structure and mRNA expression of three isoforms in adult beagles. Comp Biochem Physiol B Biochem Mol Biol 2002, 131:483-489.

27. Udagawa C, Chong YH, Shito M, Kawakami T, Tada N, Ochiai K, Ishioka K, Tsuchida S, Omi T: cDNA cloning and expression analysis of canine uncoupling protein 2 and 3 genes. J Pet Anim Nutr 2011, 14:68-75.

28. Sato K, Agoh H, Kaneshige T, Hikasa Y, Kagota K: Hypercholesterolemia in Shetland sheepdogs. J Vet Med Sci 2000, 62:1297-1301.

29. Mori N, Lee P, Muranaka S, Sagara F, Takemitsu H, Nishiyama Y, Yamamoto I, Yagishita M, Arai T: Predisposition for primary hyperlipidemia in Miniature Schnauzers and Shetland sheepdogs as compared to other canine breeds. Res Vet Sci 2010, 88:394-399.

30. American Kennel Club Home Page. http://www.akc.org/breeds/shiba_inu/ index.cfm.

31. Sugiyama S, Chong YH, Shito M, Kasuga M, Kawakami T, Udagawa C, Aoki H, Bonkobara M, Tsuchida S, Sakamoto A, Okuda H, Nagai A, Omi T: Analysis of mitochondrial DNA HVR1 haplotype of pure-bred domestic dogs in Japan. Leg Med (Tokyo) 2013, 15:303-309.

32. Parker HG, Kim LV, Sutter NB, Carlson S, Lorentzen TD, Malek TB, Johnson GS, DeFrance HB, Ostrander EA, Kruglyak L: Genetic structure of the purebred domestic dog. Science 2004, 304:1160-1164.

33. Hoffmann C, Zimmermann A, Hinney A, Volckmar AL, Jarrett HW, Fromme T, Klingenspor M: A novel SP1/SP3 dependent intronic enhancer governing transcription of the UCP3 gene in brown adipocytes. PLoS One 2013, 8: e83426.

34. Villarroya F, Iglesias R, Giralt M: PPARs in the Control of Uncoupling Proteins Gene Expression. PPAR Res 2007, 2007:74364.

35. Frischknecht M, Niehof-Oellers H, Jagannathan V, Owczarek-Lipska M, Drögemüller C, Dietschi E, Dolf G, Tellhelm B, Lang J, Tiira K, Lohi H, Leeb T: A COL11A2 mutation in Labrador retrievers with mild disproportionate dwarfism. PLoS One 2013, 8:e60149.

36. Tengvall K, Kierczak M, Bergvall K, Olsson M, Frankowiack M, Farias FH, Pielberg G, Carlborg Ö, Leeb T, Andersson G, Hammarström L, Hedhammar $\AA$, Lindblad-Toh K: Genome-wide analysis in German shepherd dogs reveals association of a locus on CFA 27 with atopic dermatitis. PLOS Genet 2013, 9:e1003475.

37. Lavriijsen IC, Leegwater PA, Wangdee C, van Steenbeek FG, Schwencke M, Breur GJ, Meutstege FJ, Nijman IJ, Cuppen E, Heuven HC, Hazewinkel HA: Genome-wide survey indicates involvement of loci on canine chromosomes 7 and 31 in patellar luxation in Flat-Coated Retrievers. BMC Genet 2014, 15:64.

doi:10.1186/1756-0500-7-904

Cite this article as: Udagawa et al:: The genetic association study between polymorphisms in uncoupling protein 2 and uncoupling protein 3 and metabolic data in dogs. BMC Research Notes 2014 7:904.

\section{Submit your next manuscript to BioMed Central and take full advantage of:}

- Convenient online submission

- Thorough peer review

- No space constraints or color figure charges

- Immediate publication on acceptance

- Inclusion in PubMed, CAS, Scopus and Google Scholar

- Research which is freely available for redistribution

Submit your manuscript at www.biomedcentral.com/submit
() Biomed Central 